\title{
Effects of Different Potassium Levels on the Growth and Development of Cordyline fruticosa Var 'Purple Compacta'
}

D. M. Udara Sampath, Shanmugalingam Srikrishnah*, Somasundaram Sutharsan

Department of Crop Science, Eastern University, Vantharumoolai, Sri Lanka

DOI: $10.36347 /$ sjavs.2020.v07i05.004

| Received: 06.05.2020 | Accepted: 14.05.2020 | Published: 19.05.2020

*Corresponding author: Shanmugalingam Srikrishnah

Abstract

Original Research Article

An assessment under shade house condition was conducted to identify the effects of graded potassium levels on vegetative growth of cordyline (Cordyline fruticosa var. 'purple compacta') plants in the Eastern region, Sri Lanka for a period of 4 months from January to April 2019 and investigation was a completely randomized design with twenty replications per treatment. Six treatments included 0.0 (Control), 0.5, 1.0, 1.5, 2.0 and $2.5 \mathrm{~g}$ of potassium/plant/month $(\mathrm{g} / \mathrm{p} / \mathrm{m})$. Muriate of potash was used as a potassium source. Nitrogen (Urea) and Phosphorous (TSP) were applied at the recommended and fixed rates of $0.5 \mathrm{~g} / \mathrm{plant} / \mathrm{month}$ and $0.5 \mathrm{~g} / \mathrm{plant} / \mathrm{month}$ respectively. Recommended agronomic practices were followed uniformly for all treatments. Growth parameters viz. plant height, leaf area, plant biomass and leaf nitrogen content (SPAD) were measured at monthly interval. Analysis of Variance was performed to determine significant difference among treatments $(\mathrm{p}<0.05)$. Results revealed that plants applied with T2 showed significantly $(\mathrm{p}<0.05)$ better performance than the other treatments in the measured growth parameters viz. plant height, leaf area, plant biomass and leaf nitrogen content. The results indicated that potassium level of $0.5 \mathrm{~g} / \mathrm{p} / \mathrm{m}$ could be the most appropriate to maximize the growth of cordyline (Cordyline fruticosa var. 'purple compacta') among the treatments used in this investigation under $50 \%$ shade condition.

Keywords: Biomass, Cordyline, Leaf area, Leaf nitrogen content.

Copyright @ 2020: This is an open-access article distributed under the terms of the Creative Commons Attribution license which permits unrestricted use, distribution, and reproduction in any medium for non-commercial use (NonCommercial, or CC-BY-NC) provided the original author and source are credited.

\section{INTRODUCTION}

Cordyline (Cordyline fruticosa) is an ornamental shrub with attractive leaves. It is a member of family Asparagaceae. C. fruticosa is an evergreen foliage plant grown in houses and landscapes. It has high demand in the export markets as cut decorative foliage [1]. Cordyline has several varieties in which, popular ones are 'Red', 'Variegated', 'Black magic', 'Rubra' and 'Green'. Cordyline fruticosa 'Americana', 'Red', and 'Purple compacta' are popular in Sri Lanka. There is immense scope of increasing productivity through adequate application of Potassium [2]. Potassium is essential for enzyme activation, osmotic control, drought resistance, carbohydrate production and partitioning [3]. Leaf growth and quality is also influenced by potassium [4]. Potassium plays significant roles in enhancing crop quality [5]. Previous resaech works identified the optimum shade [6] and nitrogen levels [7] for the cultivation of cordyline (Cordyline fruticosa var. 'purple compacta') in Batticaloa district. However, Optimum amount of potassium for Cordyline has not been identified. Hence; the objective of this study was to identify the optimum potassium level for Cordyline fruticosa var. 'Purple Compacta' in the Eastern region of Sri Lanka.

\section{MATERIALS AND METHODS}

An experiment was conducted at $50 \%$ shade house from January to April 2019 at the Crop Farm, Eastern University in Batticaloa. Experiment was arranged in a completely randomized design (CRD). Graded levels of potassium were defined as treatments viz. 0.0 (T1- Control), 0.5 (T2), 1.0 (T3), 1.5 (T4), 2.0 (T5) and 2.5 (T6) g potassium/plant/month (g/p/m). Each treatment contained 20 replications. An experimental unit consisted of one plant. Plants were arranged at a spacing of 30 plants per $\mathrm{m}^{2}$. Muriate of potash (MOP) was used as a potassium source. Nitrogen (Urea) [7] and Phosphorous (TSP) were applied at fixed rates $(0.5 \mathrm{~g} / \mathrm{plant} / \mathrm{month})$.

Recommended agronomic practices were followed uniformly for all treatments. Uniform sized $(15 \mathrm{~cm})$ and a month old rooted cuttings of C. fruticosa variety 'Purple Compacta' were used as planting materials. The cuttings were planted into polybags (diameter and height of the bags were $30 \mathrm{~cm}$ ) filled with 
potting media consists of compost and top soil in a ratio of 1: 2 (volume basis). Plant height (distance from soil surface in the pot to top most leaf by meter scale), leaf area (leaf area meter, LI-3100C), plant biomass (oven dry method) and leaf nitrogen content (SPAD - 502 meter) were measured at monthly interval. Destructive sampling method was practiced. Analysis of variance was performed to determine significant difference among treatments. Means separation was done by Duncan's Multiple Range Test $(\mathrm{p}<0.05)$. Analysis was carried out using Statistical Analysis System (SAS).

\section{RESULTS AND DISCUSSION \\ 1 Plant height}

Graded levels of potassium influenced the plant height of cordyline (Cordyline fruticosa var. 'purple compacta') significantly $(\mathrm{p}<0.05)$. Highest plant height was recorded at T2 while lowest was measured at T1 (control) at three months after transplanting (MAP) (Fig-1).

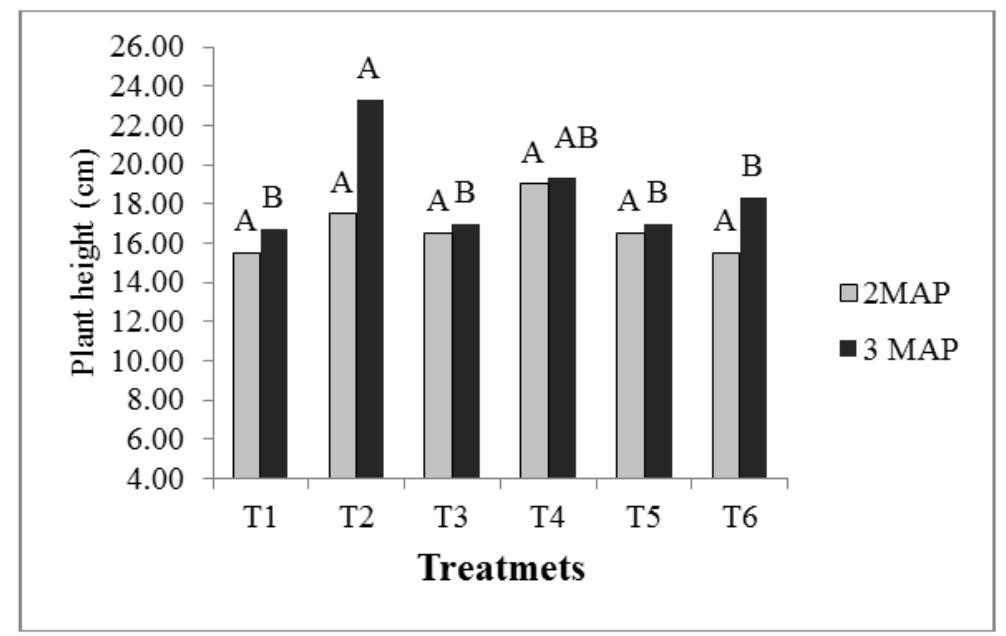

Fig-1: Effect of graded levels of potassium levels on plant height of Cordyline (Cordyline fruticosa var. 'purple compacta') at 2 and 3 months after transplanting (MAP). Bars with same letter within same MAP are not significantly different $(\alpha=0.05$; DMRT)

It was found that different levels of potassium influence plant height of $C$. fruticosa. This influence was first noticeable at three months after transplanting (Fig-1). EL-Bassiouny et al., [8] and Hossain et al., [9] reported that potassium fertilizer increased shoot height in carrot. Marschner [10] reported that, potassium is essential for enzyme activation, protein synthesis, photosynthesis, energy transfer, phloem transport, and stress resistance. Hence potassium is an essential nutrient for plant growth. Plants grown at potassium level $0.5 \mathrm{~g} / \mathrm{plant} / \mathrm{month}(\mathrm{g} / \mathrm{p} / \mathrm{m})(\mathrm{T} 2)$ showed maximum plant height while lowest plant height was recorded in T1 (control) at 3 MAT. It was observed that, plant height of cordyline decreased with increasing level of potassium in this experiment.

C. fruticosa plants produced highest plant height at T2. It could be due to optimum level of potassium received by plants. Potassium is a vital nutrient for plants and is required in higher amounts for optimum growth and development of plants. It affects plant shape and size [11]. Potassium plays major role in photosynthesis, transport of sugars and starch synthesis [5]. Abirami et al., [7] reported that optimum concentration of fertilizer can enhance the nutrient uptake. Therefore optimum concentration of potassium fertilizer can enhance the potassium uptake. This increase has a positive effect on the enzyme activation, protein synthesis, photosynthesis and phloem transport. It would cause an increased vegetative growth in plants.

Potassium is also a constituent of enzymes that are essential to the metabolic function of a plant [12]. Potassium has been reported to govern plant growth by stomatal Regulation and water uptake [5]. Egilla et al., [13] opined that, optimum amounts of potassium could enhance the growth and total dry matter accumulation of crop plants. Further Prajapati and Modi [5] stated that potassium is responsible for cell elongation as well. Therefore the increased plant height could be due to increase water uptake, leaf area, photosynthesis and elongation of cells as the plants in this treatment (T2) would have received optimum amount of potassium.

Lowest plant height was recorded at control treatment (T1) at 3 MAP. It could be due to lack of supply of potassium for their normal growth. Several authors reported that potassium deficiency could reduce the growth rate of plants. Abou El-Nasr et al., [14] pointed out that potassium plays significant role in vegetative growth parameters viz. plant height, number of leaves per plant and shoot fresh weight. Mengel and Kirkby [15] reported that potassium regulates photosynthesis, protein synthesis and starch synthesis. Potassium deficiency leads to decrease in photosynthesis and this can lead to an overall reduction in assimilate to growth [16]. 
It was also observed that, with the increasing level of potassium plant height was reduced. Plants in T3 to T6 would have received excess amount of potassium which might interrupt their normal growth. Cordyline might be sensitive to higher levels of potassium and it's photosynthetic and growth activities would have been interrupted by increased levels of potassium above $0.5 \mathrm{~g} / \mathrm{p} / \mathrm{m}$. It could be the reason for the trend observed in this experiment.

\section{Leaf Area}

It was found that leaf area (LA) of cordyline (Cordyline fruticosa var. 'purple compacta') was significantly $(\mathrm{p}<0.05)$ influenced by graded levels of potassium. Highest LA was observed at T2 while lowest was measured at T1 (control) at three months after transplanting (MAP) (Fig-2).

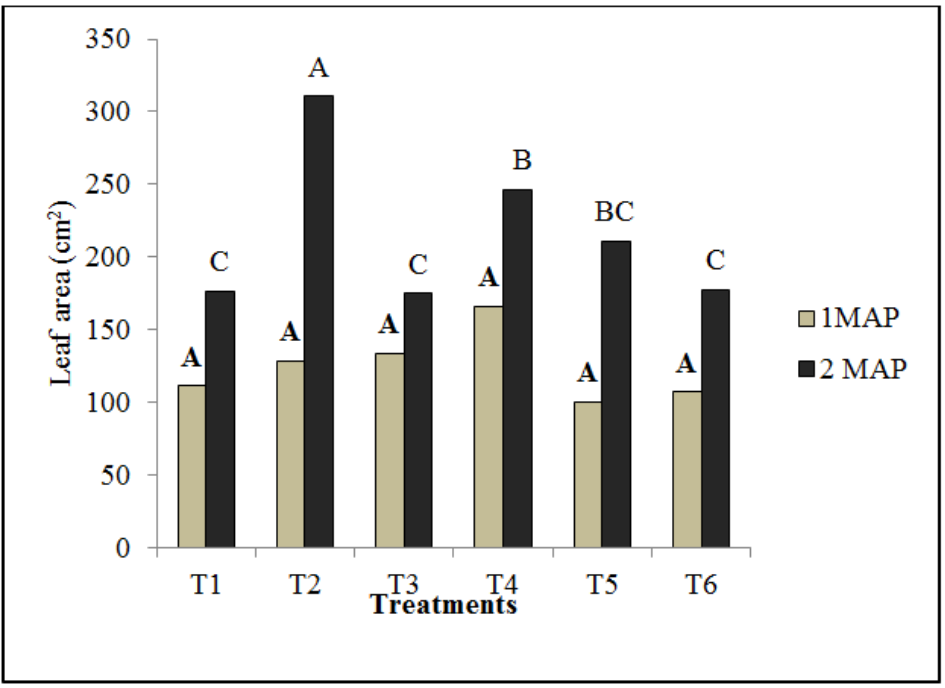

Fig-2: Effect of graded levels of potassium levels on leaf area of Cordyline (Cordyline fruticosa var. 'purple compacta') at 2 and 3 months after transplanting (MAP). Bars with same letter within same MAP are not significantly different $(\alpha=0.05 ;$ DMRT)

Leaves are the principle carrier of chlorophyll which is important for photosynthesis. It was found that different levels of potassium influence leaf area of $C$. fruticosa. This influence was first noticeable at 3 MAP (Fig-2). Several authors reported the relationship between potassium and LA. EL-Bassiouny et al., [8] found that potassium fertilizer increased number of leaves per plant in carrot. Okonwu and Mensah [17] documented that LA was increased with the application of potassium in pumpkin. Pervez et al. [18] found that highly significant relationship between potassium levels and LA in cotton.

Plants grown at potassium level 0.5 $\mathrm{g} /$ plant/month $(\mathrm{g} / \mathrm{p} / \mathrm{m})(\mathrm{T} 2)$ showed maximum LA at 3 MAP. It could be due to optimum availability of nutrients at this treatment. The increase in LA is probably due to increased availability of potassium to plants. Morris et al., [19] reported that optimum availability of nutrients is vital for efficient production and environmental safety. Mengel and Kirkby [15] stated that potassium regulates photosynthesis, protein synthesis and starch synthesis. Optimum availability of potassium could increase the photosynthesis and vegetative growth in cordyline. Increased availability of photosynthates resulted in increased LA.

Abou El-Nasr et al., [14] reported that potassium had a significant effect on vegetative growth parameters, i.e. plant height, number of leaves per plant and plant biomass. Marschner [20] reported that, potassium plays a major role in cell division and elongation and metabolism of carbohydrates and protein compounds. Hence optimum availability of potassium would increase the LA of cordyline through enhanced physiological and biochemical processes.

LA was lower in control treatment (T1). Plants grown at T1 would have received sub optimum level of potassium. It could be the reason for reduced growth of LA. Hart et al., [21] reported that optimum fertilization is essential for maximum growth and yield. Reduced availability of potassium could reduce the crop growth and LA. Pervez et al., [18] opined that the increase in leaf area due to high maintenance of nitrogen concentration in leaf tissues under sustained supply of potassium in soil-plant interface and leaf area expansion may reduce due to potassium deficiency. Mengel and Kirkby [15], reported that potassium deficiency cause reduction in growth. These could be the possible reasons for lowest LA observed in $\mathrm{T} 1$.

It was also observed that, leaf area of cordyline decreased with increasing levels (T3 to T6) of potassium in this experiment (Fig-2). Nutrient levels outside of a plant's optimum range reduce crop growth due to either a deficiency or toxicity. Potassium toxicity can cause reduced uptake and subsequent deficiencies of other nutrients [22]. Silberbush and Lips [23] reported the uptake of nitrogen is influenced by the rate 
application of potassium. Nutrient deficiencies caused by potassium toxicity would have reduced the growth of LA. Further cordyline might be sensitive to higher levels of potassium and it's growth activities would have been interrupted by increased levels of potassium. These could be the possible reasons for the lowest LA observed in T3 to T6.

\section{Plant biomass (g)}

It was found that, different potassium levels significantly $(p<0.05)$ influenced the plant biomass of cordyline. Highest plant biomass was recorded at T2 while lowest was measured at $\mathrm{T} 3$ at three months after transplanting (MAP) (Fig-3).

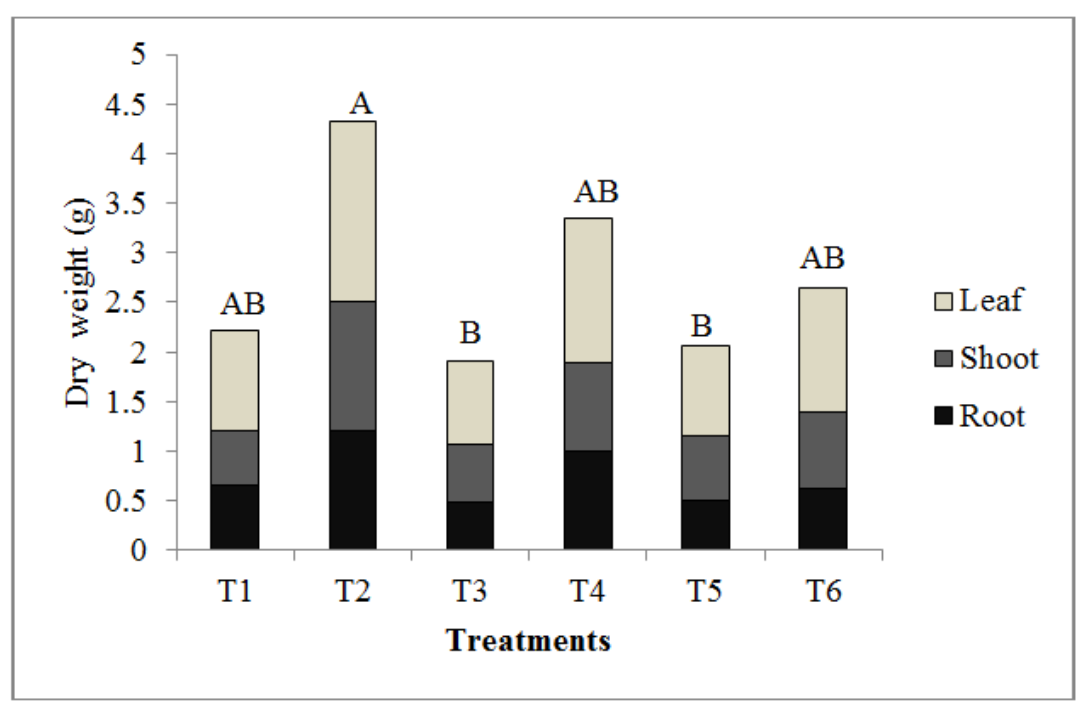

Fig-3: Effect of graded levels of potassium levels on plant biomass of Cordyline (Cordyline fruticosa var. 'purple compacta') at 3 months after transplanting (MAP). Bars with same letter are not significantly different $(\alpha=0.05$; DMRT)

Potassium plays a crucial role in the translocation and storage of assimilates [14]. Plants grown at T2 $(0.5 \mathrm{~g} / \mathrm{p} / \mathrm{m})$ produced significantly $(\mathrm{p}<0.05)$ highest biomass than plants grown at other potassium levels at 3 MAP. Plants grown at this potassium levels would have received optimum amount of potassium supply. Hence their rate of growth and photosynthesis were at highest level. Optimum amounts of potassium could enhance the growth and total dry matter accumulation of crops [13]. LA of the plants was also higher at these potassium level (Fig-2). Increased LA could also contribute for enhanced photosynthesis and subsequently plant biomass. Srikrishnah et al., [24] reported that, biomass production were in accordance with the trend of variances for LA.

Lowest plant biomass was recorded at $\mathrm{T} 1$. Plants grown at T1 would have received sub optimum level of potassium. EL-Bassiouny et al., [8] and Hossain et al., [9] reported that potassium fertilizer increased fresh weight of shoots. Hussain et al., [25] pointed out that potassium is an important element for plant growth and major component of plant dry matter. Hence optimum level of potassium is needed for maximum biomass production. Pervez et al., [18] stated that the carbon exchange rates of leaf is restricted after the onset of potassium deficiency. These could be the possible reasons for the lower biomass produced in the plants at $\mathrm{T} 1$.

Biomass of cordyline plants decreased with increasing level of potassium application in this experiment. Cordyline plants grown at T3 to T6 received comparatively higher level of potassium. Potassium plays a major role in many physiological and biochemical processes such as metabolism of carbohydrates and protein compounds [20]. Excess availability of potassium would have interfered with the carbon assimilation of plants. McCauley et al., [22] pointed out that potassium toxicity can cause reduced uptake of nutrients and subsequent deficiencies in the plant. Nutrient deficiencies due to potassium toxicity could reduce the photosynthesis and subsequent biomass production in $\mathrm{T} 3$ to $\mathrm{T} 6$.

\section{Leaf nitrogen content (SPAD value)}

Leaf nitrogen content of cordyline was significantly $(p<0.05)$ influenced by the different nitrogen levels. There was no significant difference in leaf nitrogen content between T1 and T2. However comparatively higher leaf nitrogen content was recorded in T2. Highest leaf nitrogen content was measured at T2 while lowest was measured at T5 at three months after transplanting (MAP) (Fig-4). 


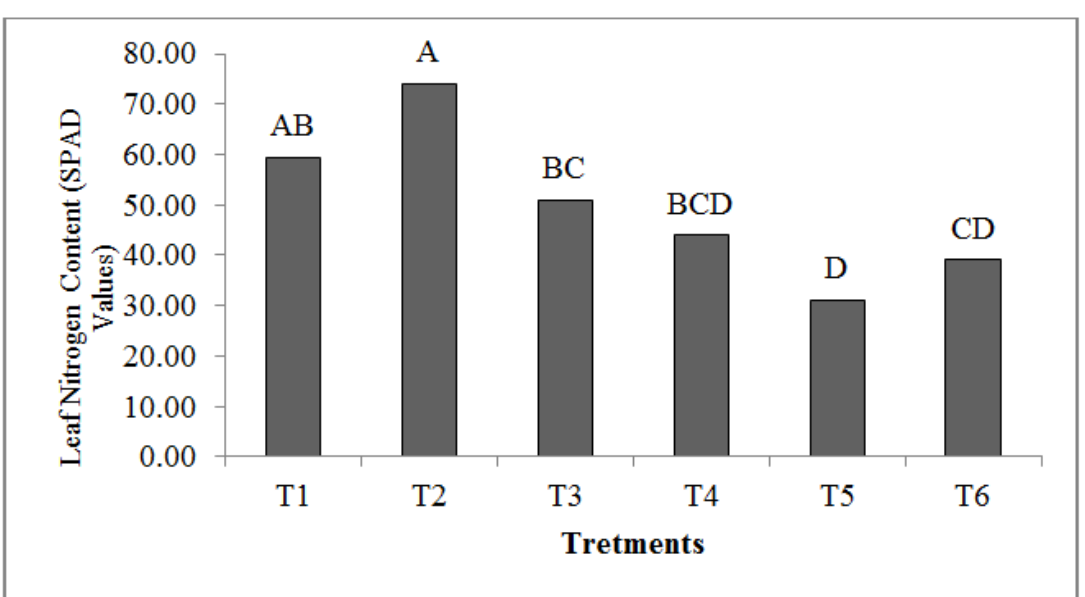

Fig-4: Effect of graded levels of potassium levels on leaf nitrogen content of Cordyline (Cordyline fruticosa var. 'purple compacta') at 3 months after transplanting (MAP). Bars with same letter are not significantly different $(\alpha=0.05$; DMRT)

The SPAD values were highly correlated with leaf nitrogen concentration [26]. Plants grown at T2 $(0.5 \mathrm{~g} / \mathrm{p} / \mathrm{m})$ had significantly $(\mathrm{p}<0.05)$ highest leaf nitrogen content among all treatments at 3 MAP. Abirami et al., [27] reported that, nutritional status of the plant has the close correlation with the leaf nitrogen content. Optimum fertilization could improve the nutritional status of the plants. Plants grown at T2 would have received optimum fertilization. Plants belong to T2 produced highest plant height, LA and biomass than plants grown in other treatments in this experiment. These findings showed that plants grown at T2 had optimum nutritional status and maximum growth rate. McCauley et al., [22] opined that optimum potassium level is essential for the uptake of other nutrients. Hence plants grown at T2 had highest leaf nitrogen content.

Plants grown at T1 would have received sub optimum level of potassium. Optimum amount of fertilizer could enhance the nutrient uptake in plants [27]. It could be the reason for the reduced leaf nitrogen content in plants belongs to T1. It was also noticed that leaf nitrogen content decreased with increasing level of potassium in this experiment. Cordyline plants grown at T3 to T6 received comparatively higher dosage of potassium. McCauley et al., [22] reported that potassium toxicity could reduce the nutrient uptake and subsequent deficiencies of other nutrients. The uptake of nitrogen is influenced by the rate application of potassium [23]. Higher dosage of potassium might suppress the uptake of other nutrients. Nutrient deficiencies caused by potassium toxicity would have reduced the leaf nitrogen content of plants in T3 to T6. These could be the reasons for the trend observed in this experiment.

\section{CONCLUSION}

Cordyline plants grown at $0.5 \mathrm{~g} / \mathrm{plant} / \mathrm{month}$ $(\mathrm{g} / \mathrm{p} / \mathrm{m})$ potassium level showed better performance in growth parameters viz. plant height, leaf area per plant, plant biomass and leaf nitrogen content. Growth of cordyline plants (Cordyline fruticosa var. 'purple compacta') decreased with increasing level of potassium in this study. It could be concluded that $0.5 \mathrm{~g} / \mathrm{p} / \mathrm{m}$ potassium level applied in split at monthly interval is optimum for growing cordyline (Cordylinefruticosavar. 'purple compacta') at 50\% shade level in the Batticaloa district of Sri Lanka.

\section{REFERENCES}

1. Weerahewa HLD, Somaratne S. Effect of some selected vase water additives on vase life of Cordyline terminalis 'red' foliage. Proceedings of Annual Academic Sessions. Open University of Sri Lanka. 2011, 257-261.

2. Arif M, Tasneem M, Bashir F, Yaseen G, Anwar A. Evaluation of different levels of potassium and zinc fertilizer on the growth and yield of wheat. International Journal of Biosensors \& Bioelectronics. 2017; 3(2):1-5.

3. Krauss A. Potash, the important part of balanced fertilization for high yield and good quality. Potash workshop, 2000.

4. Shankar MA, Sriharsha SA. Potassium for yield and quality of mulberry leaf in relation to silkworm cocoon production. Better Crops International. 1999; 13(2), 18-20.

5. Prajapati K, Modi HA. Importance of Potassium in Plant Growth. Indian Journal of Plant Sciences. 2012; 1(2):117-186.

6. Krishnakanth M, Srikrishnah S, Sutharsan S. Effects of graded shade levels on the growth and quality of Cordylinefruticosavar. 'purple compacta' in the Batticaloa district. Journal of Agricultural Sciences. 2017;11(1):17-24.

7. Abirami K, Srikrishnah S and Sutharsan S. Effects of graded nitrogen levels on the growth and quality of Cordyline fruticosa L. variety 'Purple Compacta'in Batticaloa district of Sri Lanka. AGRIEAST: Journal of Agricultural Sciences. 2018; 12(2):1-9.

8. El-Bassiouny RI, El-Seifi SK, Omar GF. Effect of potassium fertilizer Levels on baby carrot growth 
D. M. Udara Sampath et al., Sch J Agric Vet Sci, May, 2020; 7(5): 101-106

and storage ability. Journal of Agricultural Sciences, Mansoura Univ. 2002; 28(3): 2063-2097

9. Hossain AKMM, Islam MR,. Bari MS, Amin MHA, Kabir MA. Effects of mulching and levels of potassium on growth and yield of carrot. Bangladesh Research Publications Journal. 2009; 3(2): 963-970.

10. Marschner P. Marschner's mineral nutrition of higher plants, (3rd Ed), Elsevier: Amsterdam, 2012.

11. Iftikhar A. Role of potassium in plant growth. Available from https://www.slideshare.net/GhulamAsghar8/roleof-potassium-in-plant-growth. 2017.

12. Hillel D. Soil Fertility and Plant Nutrition. pp: 151-162. In: Soil in the Environment (eds. Hillel), Academic Press, London, 2008.

13. Egilla JN, Davies FT, Drew MC. Effect of potassium on drought resistance of Hibiscus rosasinensis cv. Leprechaun: Plant growth, leaf macroand micronutrient content and root longevity. Plant and Soil. 2001; 229(2): 213-224.

14. Abou El-Nasr ME, Ibrahim EA. Effect of different potassium fertilizer rates and foliar application with some sources of potassium on growth, yield and quality of carrot plants (Daucus carota L.). Plant Production, Mansoura Univ. 2011; 2(4): 559-569.

15. Mengel K, Kirkby EA. Principles of Plant Nutrition. Netherlands. Kluwer Academic Publishers, 849 p, 2001.

16. Pettigrew WT. Potassium Influence on Yield and Quality Production For Maize, Wheet, Soybean and Cotton. Physiologia Plantarum, 2008; 133: 670-681.

17. Okonwu K, Mensah SI. Effects of NPK (15: 15: 15) Fertilizer on some growth indices of pumpkin. Asian Journal of Agriculture Research. 2012; 6(3): 137-143.

18. Pervez H, Makhdum MI, Ashraf M. Influence of potassium nutrition on leaf area index in cotton (Gossypium hirsutum L.) under an arid environment. Pakistan Journal of Botany. 2006; 38(4): 1085-1092
19. Morris T, Ping J, Durgy R, Hamilton G, Seiter S, Sideman E, Anderson K. Factors influencing the soil nutrient status of organic vegetable farms in northeastern US. 18th World Congress of Soil Science, Philadelphia , Pennsylvania, USA, 2006.

20. Marschner H. Functions of mineral nutrients: micronutrients, In: Mineral Nutrition of Higher Plants, (2nd Ed), Academic Press, London, pp. 313-404, 1995.

21. Hart JM, Mansour NS, Hemphill DD, Mack HJ. Vine crops: cucumbers, melons, squash, pumpkins, Extension \& Station Communications Oregon State University, 1990.

22. McCauley A, Jones C, Jacobsen J. Plant nutrient functions and deficiency and toxicity symptoms. Nutrient Management Module. 2009; 9: 1-16.

23. Silberbush M, Lips SH, Potassium, nitrogen, ammonium/nitrate ratio, and sodium chloride effects on wheat growth: I. Shoot and root growth and mineral composition. Journal of Plant Nutrition 1991; 14(7): 751-764.

24. Srikrishnah S, Peiris SE, Sutharsan S. Effect of shade levels on leaf area and biomass production of three varieties of Dracaena sanderiana L. in the dry zone of Sri Lanka. Tropical Agriculture Research. 2012; 23(2):142-151.

25. Hussain MZ, Kumar M, Singh D, Yadav S. Effect of Different Levels of Potassium on Yield and Yield Attributes of Kharif Maize (Zea mays L.). International Journal of Current Microbiology and Applied Sciences. 2019;8(1):2054-2060.

26. Peng S, Sanico AL, Garcia FV, Laza RC, Visperas RM, Descalsota JP, Cassman KG. Effect of leaf phosphorus and potassium concentration on chlorophyll meter reading in rice. Plant Production Science. 1999;2(4):227-231.

27. Abirami K, Srikrishnah S, Sutharsan S. Effects of graded nitrogen levels on leaf nitrogen content of cordyline (Cordyline fruticosa var.'purple compacta') in Batticaloa district, Sri Lanka. Research Journal of Agriculture and Forest. 2018;6(7):7-9. 